HSS VI.1 (2017)

DOI: $10.1515 /$ hssr -2017-0002

\title{
From Eco's Apertura to Fractal Narrative: Recursion as a Tool of Order in Contemporary Narratives
}

German A. Duarte*

University of Bogota, Columbia

\begin{abstract}
In 1962 Umberto Eco published his Opera aperta. Forma e indeterminazione nelle poetiche contemporanee, in which he dealt with the televised space and its influence on the development of plot in contemporary narratives. The analysis of the aesthetic of television led him to highlight the exclusive capacity of television to transmit events in real time: Live TV. Eco affirms in particular that through the editing in Live TV, the role of choice completely changes in comparison to what happens in the editing phase within the cinematographic narrative. In Live TV, choice becomes a proper composition, a form of narrative, a means of unifying in a discursive way a set of isolated images within the framework of a wider set of events taking place at the same time and intersecting one another. This impromptu narrative brings with it the use of some recursive forms, which represent an important narrative tool enabling a weaving of the narrative space. Eco identified those recursive forms in some jazz figures such as the riff, the recursive form of which allows for the creation of an organic composition full of improvisation. A few years later, the importance of figures of this kindwas also noted by Deleuze-Guattari (1980), who posited that ritormello has an important function of organizing the exterior space, or chaotic space. Based on these considerations, this paper deals with the phenomenon of repetition, recursivity, and patterns, to bring these concepts into the construction of narrative spaces. The central point of the paper is that the birth of Live TV started a phenomenon of exteriorization of the inner data
\end{abstract}

\footnotetext{
* Universidad de Bogotá Jorge Tadeo Lozano, programa de Cine y Televisión, Carrera 4, No. 22- 61 - Modulo 7 -Séptimo Piso, german.duartep@utadeo. edu.co
} 
HSS, vol. VI, no. 1(2017): 13-33

of the narrative construction. This phenomenon of externalization makes possible the understanding of data through spatial terms, and one starts to use recursive formulas to navigate it.

Keywords

Critical Media Studies, Umberto Eco, Recursivity, Digital Media, Film Studies.

\section{Folding and Unfolding Present Time}

In his early works, Gilles Deleuze dealt with the concept of repetition and difference. This interest emerged from the fact that, according to him, in our technological context mankind is constantly facing mechanical repetitions, simulacra from which our cognition is incessantly extracting little differences, variations and modifications. Deleuze posits that repetition is the universality of the singular and that difference always implies the concept of resemblance (Deleuze, 1968: 11). As noted by Deleuze, the question, "What is the difference?" can always be transformed into the question, "What is the resemblance?" Human classification and determination imply a continuous evaluation of resemblances from which emerges the difference. Deleuze claims that repetition seems to be difference without a concept, a kind of intuition that embodies the power of the instant and resists any specification. Further, the instant determines the reality of time in which the being is aware of the existence. In Bachelard's words:

Si mon être ne prend conscience de soi que dans l'instant présent, comment ne pas voir que l'instant présent est le seul domaine où la réalité s'éprouve ? (Bachelard, 1931:14).1

Certainly, some metaphysical issues arose from the concepts noted above. The temporal notion of the instant becomes extremely important to understanding both difference and repetition. Thus, to also understanding the way in which mankind acts or imposes order on natural things and, as we will see, on narrative structures.

As noted above, the concepts of resemblance and difference are strongly tied. Resemblance, according to Deleuze, is more in the sphere of intuitions. However, if one thinks about the central role played by 
resemblance in western culture, one finds that it represents an instrument of order: an episteme. Consider, for instance, the way that resemblance guided the exegesis and interpretation of texts. Resemblance also set in motion the structure of symbols and thus allowed for the creation of concepts and representations. As noted by Foucault, dealing with the concept of resemblance, the universe was folded in upon itself and representation was a kind of repetition of nature from which derived human knowledge. ${ }^{2}$ Foucault conceived the world as something covered by signs which mankind must decipher. And these signs present some resemblances and some affinities; that is, the signs become forms of similarity. ${ }^{3}$ However, resemblance implies difference, but at the same time repetition, through which mankind can exert an act of order and can place the phenomenon in an intelligible system of signs. That is the reason why Deleuze posits that repetition is the symbolic in its essence. In his words:

Bref, la répétition est symbolique dans son essence, le symbole, le simulacre, est la lettre de la répétition même. Par le déguisement et l'ordre du symbole, la différence est comprise dans la répétition. C'est pourquoi les variantes ne viennent pas du dehors, n'expriment pas un compromis secondaire entre une instance refoulante et une instance refoulé, et ne doivent pas se comprendre à partir des formes encore négatives de l'opposition, du retournement ou du renversement. (Deleuze, 1968:32) ${ }^{4}$

This assertion brings us to consider Hume's theories developed in his Treatise of Human Nature. Hume posits that repetition does not change anything in the repeated object but it exerts a change on the spirit of the subject, on the beholder. In his words: "[...] repetition neither discovers nor causes anything in the objects, but has an influence only in the mind, by that customary transition it produces." (Hume, 2000:105). Hume's theories about repetition place us in the middle of the question: In which way does repetition change something in the repeated thing when every represented thing is independent? As noted by Deleuze, from Hume's thoughts it is possible to understand the formula of repetition.

In order to support his theory, Deleuze uses Hume's examples of the repetition of cases of type $\mathrm{AB}, \mathrm{AB}, \mathrm{AB}, \mathrm{AB}, \mathrm{A} \ldots$... As one can note, each 
objective sequence $\mathrm{AB}$ is perceived as independent from the others. Repetition doesn't change the state AB. However, there is a change, but it is produced in the mind of the beholder. It produces a difference, something new in the mind (Deleuze, 1968: 96). Whenever I observe A, I expect the appearance of $\mathrm{B}$. It is possible to see that my subjectivity plays a role in the constitution of repetition. One might suppose that seriality generates a kind of cognitive necessity in which the beholder's perception is affected and creates repetition. Thus, it is the human imagination that exerts a contractile power, "(...) plaque sensible, elle retient l'un quand l'autre apparait." (Deleuze, 1968: 96). ${ }^{5}$ From the phenomenon of contraction exerted by the human mind emerge some interesting conclusions about time, and more importantly for this text, about the narrative construction developed by visual media.

As noted above, when A appears, I await B. This phenomenon, following Hume's theories, is due to the act of contracting exerted by human imagination, which, in this way, melts the elements. Thus, when I see A, my imagination contracts into this A the case B. Hence, following Deleuze's thoughts, one can posit that A is a synthesis of time. Further, it is also possible to state, through Bergson's theories, that perception is never a mere contact between the spirit and the present object. According to Bergson, memory is a sui generis act through which humankind becomes conscious and through which mankind's mind is able to break loose of present time in order to be placed on some region in the past. For Bergson, the human act of memory is analogous to putting an image into focus in a photographic camera. ${ }^{6}$ However, by establishing a difference between memory and perception, aiming at analyzing time as a becoming entity, Bergson places perception into the present and memory in the past, because perception moves memory into an earlier time. Nevertheless, memory can also exist in the present because it can be placed in the time of becoming, in this instance of bic et nunc, which is in perpetual becoming. As one can see, one is dealing again with the notion of instant, but this time we have a new notion that becomes fundamental for our analysis, the notion of becoming (devenir). As already noted, the instant determines the reality of time -which, according to Bergson, is indivisible and in eternal becoming - and it is in time that the being is aware of its existence. Consequently, the notion of 
becoming in which mankind is placed brought Bergson to claim that "my present" (mon présent) is a perception of my immediate past and also a determination of my immediate future. Going back to Hume's examples and following Deleuze's analysis, time is constituted in the synthesis operating on the seriality of instants, a synthesis that contracts or melts the seriality of independent instants. Consequently, it is in this present that time is deployed, and this present is the owner of future and past. Following this framework, past, as well as future, do not represent instants but dimensions of the present. The contraction or synthesis proposed by Deleuze is a passive synthesis because it occurs in the mind of the beholder and is prior to memory and reflection. Consequently, according to Deleuze, time is subjective, but it is the subjectivity of a passive subject (Deleuze, 1968: 97). Thus, one could say that there exists only a present time, which is subjective, multidimensional and embraces the dimensions of past and future. Hence, it is through this present that time unfolds.

In the following sections, I will focus on the role played by recursive formulae, resemblance, and similarity, in ordering information. But, above all, I will examine how iteration has become, within a specific technological context, a primary narrative tool,a tool that allows the viewer to unfold a diegetic narrative time.

\section{From Seriality to Navigability in the Narrative Field}

The analogies to the cinematographic camera start to become clear. The cinematographic camera is able to develop only a present time from which the human mind unfolds past dimensions (flash backs) and future dimensions (flash forwards). The fact that the cinematographic image is always actual represents an important feature that creates a fundamental distinction between cinematographic technology and both photographic technology and linguistic processes. Further, the conjunction of real and unreal theorized by Barthes and achieved through photographic technology - where the real is represented by the real existence of the object translated into the photographic dimension and the unreal by its absentia confirmed by the representation - loses its unreal component. This happens by means of the movement accomplished in front of the beholder: movement puts the object that is in absentia into presentia. 
Certainly, through the representation of movement, the film camera escapes from the punctum temporis of photographic technology. ${ }^{7}$ However, the film camera's capacity to unfold the present time is exclusively developed through editing. It is through editing that "two film pieces of any kind, placed together, inevitably combined into a new concept, a new quality, arising out of that juxtaposition.”(Eisenstein, 1943: 14).

If one analyzes the Kuleshov effect, which represented a kind of scientific guarantee to the editing, it is from the juxtaposition of images that the association of ideas is derived, and by means of them - and through them -the beholder recognizes, or finds, an experience of life, a meaning. According to the Mitry'sinterpretation, cinematic images identify with stimuli that initiate a process consisting of reviving emotions or ideas through the reminiscence or awareness of the effect of past experiences. ${ }^{8}$ Hence, Mitry argues that the experience of Kuleshov's "the girl on the sofa" has no meaning if the beholder is a child who does not know sexual desire yet (Mitry, 1963b: 283). By means of this experience, it is possible to demonstrate that, as the girl does not express anything, what the beholder saw was not real. In other words, the viewer, in front of a succession of frames, links the series of successive perceptions and brings each of them to an "organic whole." Then, he or she builds logical relations and attributes expressions (or meanings) to what should be expressed or, in that case, to what she should have expressed. The girl on the sofa imposes a relation, man looking-girl looked, that recalls and signifies the idea of desire.

The Kuleshov effect was the enlightenment of the mechanism creating meaning in moving pictures. Through this effect, a number of theories attempted to establish some automatism in the relation: imagebeholder. Following Bonitzer, these automatisms attempted to create an imaginary "healing" of the fractionated space through editing (Bonitzer, 1982: 28). Further, the Kuleshov effect demonstrated a kind of necessity, on the part of the beholder, for continuity and unity of the space; in other words, a need for homogeneity in the heterogeneous succession of different shots. The change, as in Hume's example, is produced in the beholder's mind: seriality produces a difference, something new in the beholder's mind. As a consequence, editing started to be seen as the most important element of cinematographic art (See Mitry, 1963a). This 
is the case for Pier Paolo Pasolini, who stated that editing governs the narrative instrument of film, because it organizes the narrative, chooses the "significant moments," and can also transform a current (= present) image into a "past sentence." To be precise, editing can transform present into past but, at the same time, this past remains present because of the nature of the image, which is always actual (Pasolini, 2000). However, the fruition of the narrative is determined by the technology used in the construction of it. This is precisely Umberto Eco's premise in his study on Live TV, which appeared in his fundamental work Opera Aperta. Forma e indeterminazione nelle poetiche contemporanee. In that work, Eco dealt with the televised space and its influence on the development of the plot in contemporary narratives. By analyzing the aesthetics of television, he highlighted the exclusive capacity of television to transmit events in real time: Live TV. However, before dealing with the phenomenon of Live TV, I would like to make a short digression on the nature of the video image and other changes brought by this technology. In fact, as we will see, video technology makes possible a different understanding of the narrative space. And it seems to me that, in a way, it is through this new understanding of the narrative space that the viewer started to develop the desire to navigate through the narrative and, above all, started to be part of the creative process.

\section{Time Becoming Image}

From a technical point of view, the most relevant change brought by video technology in the nature of the image is that the video image creates another kind of continuum. The points that are spread through the images in a temporal succession compose video lines invisible to the viewer. The temporal succession implies that the variation of points, which are never visible at the same time, is constituted in time and less in space: it is an interval. Hence, the development of a video image is based on the intervals between the points. The very elementary condition of reproducing an image by means of video technology is that the intervals, the variation of points, are allowed. Consequently, the electronic image imposes an inner change, a variation of its minimal components (the points), which are only punctual in character; they represent a momentary entity in continuous becoming (Engell, 1999: 471). Further, 
according to Engell, the dimension of the video image is not able to contain elements. The video dimension contains, in Engell's words, nichteinfach-vorbanden-bleiben-können elements (elements that cannot just continue to exist, Engell, 1999: 470). In other words, this dimension contains a continuum, a set of transformations. The perpetual becoming of this space develops both a virtual image and an actual image that are indivisible. As stated by Engell, the perceived image is never present because it is composed of two coalescent images that create a unity that presents both an actual and a virtual image. The actualization of an image in the unity also means the virtualization of the former image. The actuality is assured by the continuity of the image in the present time, which is in fact a changing present or a present that goes by. For this reason, Engell points out that television is time that becomes image. Certainly, the technological change from a photographic technology to an electrical image allowed for cable transmission that also generated the feeling of possessing an endless space in constant becoming. Cubitt understood this phenomenon as the incessant flow of TV broadcasting, where the VCR played a fundamental role in materializing the instant, in unfolding a present time from the incessant flow.

If we consider the mechanisms of the creation of a narrative in the audiovisual field as the relationship between objects in presentia (syntagma), and objects in absentia (paradigm or hors-cadre), one might suppose that the construction of a narrative through the incessant flow of images, of the continuum generated by video technology, imposes a different approach. It is possible to consider that the incessant flow of images in TV represents an infinite paradigm in a state of continuous becoming, and the VCR embodies a device that brings those images into presentia; it creates an instant. In cubit words: "The domestic video cassette recorder (VCR) is itself a kind of production device, as it can be for seizing moments from TV's incessant flow, compiling, crash editing."(Cubitt, 1991: 4). Further, according to Cubitt, the organization of the incessant flow using the VCR required a new kind of capacity of the viewer to organize a narrative. ${ }^{9}$ Borrowing from Cubitt: "These complex modes of storytelling in video - spatial orientation, time orientation, knowing who to believe and who to disbelieve - demands equally complex work on the part of the viewers..."(Cubitt, 1991: 6).The 
viewer started to be involved in a different way in the creative process. It started to be part of the choice, which is the act that embodies editing. Maybe due to the new character of the image, which started to embody a continuum, the viewer, with the VCR, could start to build its narratives through moving images. Certainly, this social phenomenon started to develop a new understanding of narrative structure, a structure similar to that highlighted by Umberto Eco in the 1960s.

The first aspect that took Eco's interest in Opera aperta was the choice in Live TV, that is to say, the editing of live events. As Eco noted, the director mixes at least three different cameras simultaneously. Thus, through the editing in Live TV the viewer watches an interpretation of the event. As one can suppose, the choice in this case changes with regard to the cinematographic choice in the editing phase. The choice in Live TV is for Eco a kind of composition, an integration or unification of images that can be analytically isolated within a wider series of events that are present contemporaneously and are intersecting one another. ${ }^{10} \mathrm{It}$ is important to remark that Eco identified the necessity of recursivity to construct the narrative space in Live TV. This impromptu represents an important narrative tool that enables the weaving of a plot. In fact, by using at least three cameras, the director constructs, through recursion, the narrative in the moment, and Eco sees in this practice some similarities with the recursive forms of some jazz elements, like the riff. Indeed, the recursive form of the riff allows the creation of an organic composition full of improvisation. The use of repetition, or recursion, represents the most evident change in the construction of the narrative. Following Aristotle's Ars Poetica, the choice of some of the actions of a whole event creates a narrative unity. On the contrary, in Live TV, the director's aim changes because one is obliged to institute immediately both a coherence and a unity within the chaos of events (Eco, 20067: 194). The director is obliged to isolate single facts from the whole event that is happening: Live TV establishes a new relationship between the stylistic device (artificio) and the spontaneity (spontaneita). To borrow from Eco:

La crescita della sua narrazione appare così per metà effetto d'arte e per l'altra metà opera di natura; il suo prodotto sarà una strana interazione di 
spontaneità ed artificio, dove l'artificio definisce e sceglie la spontaneità ma la spontaneità guida l'artificio, nel suo concepimento e nel suo compimento. (Eco, 2006 ${ }^{7}$, p. 197). ${ }^{11}$

As a consequence, Eco highlights the inclination of the contemporary narrative toward the dissolution of plot (dissoluzione dellintreccio), where the plot is understood as the position of unambiguous links among the events that turn out to be essential to the final denouement. However, Eco remarked that contemporary narratives express what he calls "unessential facts." Consider, for instance, the facts that occur to Leopold Bloom or to some characters of Robbe-Grillet. Nonetheless, those unessential facts are essential in the diegesis; they represent a development of the plot, and it is precisely in the presence of those apparently unessential facts that Eco sees the apertura of the contemporary narrative. For Eco, the apertura means the possibility to recognize a chaotic world. Borrowing from him: "Nel rifiuto dell'intreccio si attua il riconoscimento del fatto che il mondo è un nodo di possibilità e che l'opera d'arte deve riprodurre questa fisionomia." (Eco, 20067: 199-200)..$^{12}$

At this point, I would like to draw your attention to the phenomenon of apertura manifested in the audiovisual field. Eco noted this phenomenon in some films by Antonioni, mainly in L'avventura (1960) and La notte (1961). Concerning these films, Eco wondered if a viewer alienated from the practice of Live TV could accept a narrative like that of Antonioni's in which the viewer can find scenes that manifest a kind of primary narrative material that generates the illusion of seeing a natural succession of events. In these films by Antonioni there are moments in which the plot is completely undone, moments in which nothing happens (Eco, 20058: 319). Hence, Eco compares the narrative structure of L'avventura to the narrative construction of Live TV. He posits that in L'avventura, the viewer could ask him- or herself if some scenes were made the same was as Live TV, that is to say, if the images were "broadcasted in real-time." Further, Eco posits that in some of Antonioni's scenes, as well as in Live TV, there is an attempt to represent the multidimensionality of live without the use of prefixed links (Eco, 20067: 201). One can say that in these narrative constructions 
they are a simulation of the prefixed links, and further, one is dealing, while editing, with casualness. But, as remarked by Eco, Live TV deals with a casual casualness component, contrary to Antonioni's L'avventura, which deals with a wanted casualness (Eco, 20067: 201). In consequence, both narrative constructions do not attempt to create a plot in the classical sense because both directors attempt to communicate a kind of indeterminacy. In Eco's words:

Il racconto, come intreccio, non esiste proprio perché nel regista c'è la calcolata volontà di comunicare un senso di sospensione e di indeterminazione, una frustrazione degli istinti 'romanzeschi' affinché questi si introduca fattivamente al centro della finzione (che è già vita filtrata) per orientarsi attraverso una serie di giudizi intellettuali e morali. L'apertura presuppone insomma la lunga e accurata organizzazione di un campo di possibilità. (Eco, $2006^{7}$, p. 202). ${ }^{13}$

One can see the difference from the traditional plot generated within an Aristotelian logic, in which the world is presented under prefixed laws, logic and functional ways that are deterministic and represent a determined world. In this new way of structuring the narrative, the fundamental difference in organizing the plot is the dissociation of the classic links through which the world was represented and life was told (See Duarte, 2014). Certainly, in the period in which Eco wrote these thoughts, the materiality imposed by the film stock and its linearity allowed only a phenomenological analysis. In fact, the dissolution of dramatic knots required a phenomenological change that could liberate the viewer from the millenary attitude of how it ends. However, it is possible to suppose that the depth change exerted by the remediation exerted by Live TV in the organization of the narrative structure could be identified in the presence in syntagma of some events or objects usually placed in paradigm. In other words, one started to externalize the paradigm. To follow a more adequate terminology for our technological context, there was a real externalization of database, through which database and interface became a single, heterogeneous, multidimensional space.

As already noted, Eco saw some similarities between some jazz forms and the organization of the chaotic events of Live TV. We also saw that in Live TV one is dealing with casual casualness, and thus, the director is 
creating an organic composition full of improvisation. However, it is an improvisation that finds in the repetition of a pattern, in a recursive formula - like in the case of the riff in jazz music - a way of organizing chaos. The indeterminacy noted by Eco, which he sees as a set of possibilities, joins Leibniz's ideas about chaos. In fact, according to Leibniz, chaos is a set of possibilities, the non-coordination of individual essence (Deleuze, 1988). Further, when Eco posits that "the opening presupposes, in short, a long and accurate organization of a field of possibilities" (Eco, 20067: 202), in my view, he is foreseeing the ergodicity of the medium that digital technology accomplished some years later. But at the same time, by recognizing the chaotic character of nature, he was also highlighting the importance of recursivity in the organization of the narrative space. The riff for Umberto Eco, or the ritornello (refrain) for Deleuze, represents an instrument the recursivity of which one uses to organize chaos: one territorializes a field of possibilities. According to Deleuze-Guattari, improvisation means to join the world or to be part of it (Deleuze and Guattari, 1980: 383). The exampled used by DeleuzeGuattari to introduce the subject of recursivity as a tool of territorialization is a child in the dark singing a refrain - using this recursive path - to territorialize darkness (Deleuze and Guattari, 1980: 381-433). Through these thoughts, it is possible to understand recursivity as a tool for creating semiotic vectors from the amorphous. That is to say, recursion is an act of anamorphosis: an act of taking form from the formless.

As one can note, on the one hand, we have Hume's examples, which place the subject in front of a serial order, a sequence, and we saw the way in which it affects the subject: the way in which repetition affects the soul. On the other hand, we have the example of the subject facing chaos. In this second case, seriality, or repetition, used by the subject, represent an instrument to organize it. Like the ritornello, the riff in jazz music or the repetition through cameras in a Live TV broadcast, the subject does not follow the linearity imposed by the object; the subject is trying to territorialize the space through recursive formulas. If one projects these phenomena to narrative constructions in the audiovisual field, it is possible to state that the first case, the case in which the subject, the viewer, undergoes in a passive way the seriality that affect his 
mind, could be assimilated to the Kuleshov effect. The collision of two images in the linearity imposed by the film stock places the viewer in the condition to gather meanings. Time is unfolded, and meaning is created in the sequentiality. Conversely, in the second case, through the externalization of the database, the subject not only perceives the narrative construction through spatial terms, but also the subject uses recursivity to territorialize the database. The subject uses recursive formulas to organize the narrative space. Consequently, the viewer starts to play a role in the organization of the narrative structure. However, as we will see in the next section, it is through the disappearance of a clear distinction between the two well-defined spaces, the database and the interface, that one starts to consider the narrative as a pure spatial construction. In addition, one also starts to realize that, through the navigation of the database, which, in our technological context is infinite and in continuous becoming (e.g.YouTube), one is also creating a narrative structure that places itself in a new relationship with the machine. Sometimes these structures are created unconsciously; consider, for instance, the creation of "suggestions" on a YouTube page, which are created using algorithms, and sometimes the narrative externalizes its ergodicity, as is the case in ergodic cinema.

\section{Topical or Topographical: the Territorialization of the Database}

The acknowledgement of the phenomenon of the externalization of database was in my view accomplished through the development of digital technology and its presence in audiovisual narratives. In fact, it was through digital technology that narrative structures generated the need for integrating paradigm and syntagma, which in this technological context were fully understood as database and interface. Antonio Caronia gives an interesting example of this in his analysis of postsymbolic communication. He highlights within digital narratives a phenomenon of externalization of cognitive elements, which produces another cognitive level as well as a new communicative level. Borrowing from Caronia:

La logica di questo nuovo livello influenza tanto l'organizzazione interna dei dati (il database) quanto la loro rappresentazione e la loro comunicazione alla 
HSS, vol. VI, no. 1(2017): 13-33

componente umana (l'interfaccia), e rivela possibilità espressive in entrambi gli ambiti. (Caronia, 2006: 127). ${ }^{14}$

Certainly, digital technology imposed a new organization of data, which not only takes into account the classification, order and navigability of data presented to humans through the interface, but also the order in the former inner data: the organization of database (Vesna, 2007). If we follow Morin's thoughts about knowledge and information, one can suppose that the externalization of database represents a radical change in the production of knowledge. In fact, Morin associates knowledge with organization, differing from the concept of information, which is a simple computation (Morin, 2005: 145). Through the fullyaccomplished exteriorization of database allowed by digital technology, we find ourselves facing the thousand-year-old human will of converging, in a single location, the totality of human knowledge. ${ }^{15}$ Consequently, the convergence of human knowledge in the immaterial database, and its exteriorization, brought a new approach to the inner order of knowledge: one started to abandon the topic order that governed the encyclopedic structure, or the organization of libraries, and started to understand, through the network, a web of topics, which recalls the etymological meaning of the Greek word topos ( $\tau 0^{\prime}$ ' means "place." Further, in the web of topics, described through the externalization of the database, one started to see the absence of hierarchy.

The changes in the construction of the narrative space in cinematography and television, highlighted above, represent the way in which progressively the inner organization of data started to be seen as a pure spatial organization. Further, as already noted, this new way of organizing data, and, consequently, narrative structures, encourages the use of recursive formulas to territorialize the narrative space. In my opinion, the territorialization of data in the audiovisual field manifested itself in many different ways. What is important to note is that in this process of territorialization, in the construction of a new understanding of the relationship between objects in absentia and objects in presentia (database-interface), one started to approach the topos as a navigable space. Within the limits imposed by the film stock as a material medium, 
one can see that some films started to pursue a kind of hypertextuality. Film narratives started to leave the phenomenon of simple reflection, or myse en abyme, in which the story contains another story - e.g. Truffaut's La nuit américaine (1973) or Fellini's 81/2 (1963) - placing the film into the film, and started to deal with the notion of an infinite web of heterogeneous components. In other words, some films started to manifest the existent of a database of the whole universe of filmic images. It is possible to identify this new reflexive character of the cinematographic image in the mechanisms of "quotations" or "footnotes" introduced in some films during the 90s. Consider, for instance, Altman's The Player (1992). This mechanism of quotations shows how the images are placed in the constellation of the film, in the archives of styles. The cinematographic image starts being able to express meta-films (Fahle, 2005: 105). Following the framework developed in this text, the single image becomes an interface of the whole database of filmic images. Thus, the system of filmic presentation becomes a point of view on a database.

The phenomenon of meta-film was analyzed by Eco as an intertextual dialogic (dialogismointertestuale). According to him, this is a common effect in postmodern narratives that are a part of mass communication. As an example, Eco notes the common practice of ironic quotations of topos in mass communication. He sees this system of quotations in Woody Allen's Bananas (1971), in the scene in which Allen "quotes" the mythical scene of the Odessa Steps taken from Eisenstein's Battleship Potemkin (1925). As remarked by Eco, this system of quotations, the intertextual dialogic, appeals to a kind of "encyclopedic vision" of the viewer. In fact, in order to understand the allusion, the viewer must know the original "places," the original topoi (Eco, 1985: 131). Eco's conclusion allows us to see that the narrative act started to be understood more as a topographic action than as a hierarchical organization of events, images or thoughts. ${ }^{16}$

Let us take the previous example, Eisenstein's Battleship Potemkin, to see how this topos underwent the transformation, motivated by the technological change from analog film, passing through video technology, to digital technology. 
In 1987, Zbigniew Rybczynski completed Steps, a film based on the incrustation of video images on a space developed through analog film. The plot of this film is based on a virtual journey through Eisenstein's legendary Battleship Potemkin (1925): a group of American tourists "travel" inside the scene of the Odessa Steps. As noted by Manovich, in Steps, "Rybczynski connects three generations of fake-reality technologies: analog, electronic, and digital." (Manovich, 2001: 150). Further, in these three generations of technologies, and especially in the narrative construction of Steps, it is possible to see, thanks to the hybrid nature of video technology, the conceptual tendency toward navigability of the narrative space inherent to digital narratives. And the same phenomenon also occurs in other cinematographic works of the Nineties. To name but one example, the acknowledgment of the phenomenon of the exteriorization of database represents the conceptual basis of The Pillow Book (1996) by Peter Greenaway. In this film, there is a manifestation of the structural narrative process. The very narrative structure of the film seems to be composed by a number of separated objects stored independently. ${ }^{17}$ Thus, the viewer has the feeling that the database, objects usually in absentia, started to be present in the diegesis: starts to be in presentia. Through Greenaway's film, it is possible to see that we are no longer dealing with the dissolution of the plot theorized by Eco; The Pillow Book presents a vague diegetic time through the externalization of the inner space of the narrative. Consequently, the viewer interprets some sub-frames as future or past actions in the diegesis. The viewer becomes in this way active: he/she has the feeling of navigating through present frames and sub-frames and through this allusion to navigation the viewer folds and unfolds time. Further, this fractal composition of the narrative structure expunged the Aristotelian view of the narrative seen as a linear series of event with a beginning and an end, and the viewer, facing a space made by isolated events, progressively starts to become a user, a viewser that navigates a database, that organizes the narrative space. The status of viewser finds an interesting analogy in some film characters of the Nineties. Consider, for instance, the role of Phil Connors (Bill Murray), the leading character in Harold Ramis' Groundhog Day (1993). Here, the film is constructed by using a self-similar pattern covered by Phil Connors. The recurrent 
narrative starts at six o'clock in the morning of February 2 when the clock-radio starts to play I got you, Babe by Sonny \& Cher. In this film, the protagonist is forced to learn to live in a recursive pattern, in a recursive world. No matter what he does - even if he kills himself - the pattern starts again, and again, and again at six o'clock with the song I got you, Babe. The same phenomenon can be seen in the film Run Lola Run (1998) by Tom Tykwer in which the narrative structure is composed of three well-defined patterns and in which the character can only react to the pre-established pattern thus showing that a small change in the original data completely changes the final effect. However, as already noted, the externalization of the database generated a phenomenon of an allusion to its navigability. This phenomenon was identified in many different ways, each one highlighting a single minor difference. It can be hyperlinking cinema, neo-baroque film, post web cinema: all of them deal with the allusion to the navigation of a fractal narrative space represented by an infinite database. This includes Magnolia (1999), Timecode (2000), Amores Perros (2000), Babel (2006), among others. All these films respond to the same necessity: to conceptually recognize the navigability of the database limited by the materiality of the medium: the film stock. Further, these films, each one in a different way, use repetition and recursive patterns as narrative tools that enable the organization of the chaotic character of real life. And, in doing so, the narrative starts to reveal its inner structure. In such a structure, the aim of the protagonist is to be aware of its being an infinitely repeatable element that develops its existence into a rule-governed pattern. Consequently, as Cubitt posits, in this neobaroque gestalt, "[t]he diegesis is a knowledge base, its secrets resources to be picked up and used, like the energy and weapons in computer shoot-'em-ups.'(Cubitt, 2004: 240).

Digital technology fully allowed the navigability of the database. However, our technological context is characterized by a cohabitation of analog - and, consequently, linear narrative structures - and digital narratives. Progressively, digital technology is becoming more present in every field, but we are still maintaining some narrative constructions that, in my view, do not correspond to the digital logic, that are, in other words, linear. Nevertheless, it is possible to see that in the last decade there has been a consistent increase in prequels, sequels, spin-off, and so 
HSS, vol. VI, no. 1(2017): 13-33

on. One could posit that this increasing production corresponds to a need inherent in an audience that is familiar to the possibility of navigating the database. In other words, we are now dealing with a viewser accustomed to having an active role when dealing with information, a viewser that constructs for him- or herself the narrative structure by navigating through the database, aviewser that, if he or she had the opportunity to navigate through Breaking Bad's database, would certainly investigate by themselves the interesting life of the character Saul Goodman before becoming Walter White's lawyer.

\section{References}

Bachelard, G. (1931).L'Intuition de l'instant. Paris: Stock.

Bergson, H (1986). Matière et mémoire. Paris: F. Alcan.

Bolter, J.D. (1991).Writing Space: The Computer, Hypertext, and the History of Writing. New Jersey: Routledge.

Bonitzer, P. (1982). Le champ aveugle. Ligugé: Cahiers du Cinéma.

Caronia, A. (2006). 'L'incoscio della macchina. Ovvero: come catturare il significante fluttuante," In A. Caronia, E.Livraghi and E. Pezzano (eds). L'arte nell'era della producibilità digitale. Milano: Mimesis. 125-140.

Couchot, E. (2007). Des images, du temps et des machines dans les arts et la communication. Paris: Éditions Jacqueline Chambon-Actes Sud.

Cubitt, S. (1991). Timeshift. On video Culture. London: Routledge.

Cubitt, S. (2004). The Cinema Effect. Cambridge (Mass.): MIT Press.

Deleuze, G. (1968). Différence et répétition. Paris: Puf.

Deleuze, G. (1988). Le Pli, Leibniz et le baroque. Paris: Minuit.

Deleuze G. and Guattari F. (1980). Capitalisme et schizophrénie 2. Milleplateaux. Paris: Minuit.

Duarte, G.A. (2014). Fractal Narrative: About the Relationship Between Geometries and Technology and Its Impact on Narrative Spaces. Bielefeld :TranscriptVerlag.

Eco, U. (1962). Opera aperta. Forma e indeterminazione nelle poetiche contemporanee. Milano: Bompiani, $2006^{7}$.

Eco, U. (2005). Apocalittici e integrati. Comunicazione di massa e teorie della cultura di massa. Milano: Bompiani, 2005 $5^{8}(1964)$.

Eco, U. (1985). Sugli specchi e altrisaggi. Il segno, la rappresentazione, l'illusione, l'immagine. Milano: Bompiani.

Einsenstein, S.M. (1943). The Film Sense. London: Faber and Faber. 
HSS, vol. VI, no. 1(2017): 13-33

Elsaesser, T. (2009). "Tales of Epiphany and Entropy: Around the Worlds in EightyClicks," In: P. Snickars and P. Vonderau (eds). The YouTube Reader. Stockholm: National Library of Sweden. 166-186.

Engell, L. (1999). "Fernsehenmit Gilles Deleuze," In: O. Fahle and L. Engell (eds). Der Film bei Deleuze/Le cinema selon Delenze. Weimar: Verlag der BauhausUniversität/Presses de la SorboneNouvelle. pp. 468-481.

Fahle, O. (2005). Bilder der Zweiten Moderne, Weimar: VDG.

Foucault, M. (1966). Les mots et les choses. Paris: Gallimard.

Hume, D. (2000). A Treatise of Human Nature. Oxford: Oxford University Press.

Kessler, F. and Schäfer, M.T. (2009). "Navigating YouTube: Constituting a Hybrid Information Management System," In: P. Snickars and P. Vonderau (eds), The YouTube Reader. Stockholm: National Library of Sweden. 275-291.

Manovich, L.(2001). The Language of New Media. Cambridge (Mass.): MIT Press.

Manovich, L. (2007). "Database as Symbolic Form," In: V. Vesna (ed)Database Aesthetics, Art in the Age of Information Overflow. Minneapolis: University of Minnesota Press. 39-60.

Mitry, J. (1963²). Dictionnaire du cinéma, Paris: Larousse,.

Mitry, J.( 1963 b). Esthétique et psychologie du cinéma, vol 1. Paris: Cerf.

Morin, E. (2005). Introduction à la pensée complexe. Paris: Seuil.

Pasolini, P.P. (2000). Empirismo eretico, Milano: Garzanti.

Stiegler, B. (2009). "The Carnival of the New Screen: From Hegemony to Isonomy," In: P. Snickars and P. Vonderau (editors). The YouTube Reader. Stockholm: National Library of Sweden. 40-59.

Vesna, V. (2007). "Seeing the World in a Grain of Sand: The Database Aesthetics of Everything," In: V. Vesna (editor). Database Aesthetics, Art in the Age of Information Overflow. Minneapolis: University of Minesota Press. 3-38.

Zinna, A. (2004). Le interfacce degli oggetti di scrittura. Teoria del linguaggio e ipertesti. Roma: Meltemi.

1 "If my being is aware of itself only in the present instant, how can anyone fail to see that the present is the only domain where reality is proven?"(My translation) ${ }^{2}$ Foucault, 1966: 32. "Le monde s'enroulait sur lui-même : la terre répétant dans le ciel, les visages se mirant dans les étoiles, et l'herbe enveloppant dans ses tiges les secrets qui servaient à l'homme. La peinture imitait l'espace. Et la représentation - qu'elle fût fête ou savoir - se donnait comme répétition : théâtre de la vie ou miroir du monde, c'était là le titre de tout langage, sa manière de s'annoncer et de formuler son droit à parler." 
${ }^{3}$ Hence knowledge for Foucault means interpretation, and interpretation is based on exterior correspondences. Further, Foucault claims that divination is part of knowledge because the interpretation of signs does not mean the discovery of hidden things due to the phenomenon of resemblance (Foucault, 1966: 48).

4 "In short, repetition is in its essence symbolic; symbols or simulacra are the letter of repetition itself. Difference is included in repetition by way of disguise and by the order of the symbol. This is why the variations do not come from without, do not express a secondary compromise between a repressing instance and a repressed instance, and must not be understood on the basis of the still negative forms of opposition, reversal or overturning." (Gilles Deleuze, Difference \& Repetition, Continuum, London - New York 2001: 17)

5 “(...) sensitive plate, it retains one when the other appears." (My translation) ${ }^{6}$ See Bergson, 1896, esp. Chap. III, De la survivance des images. La mémoire et l'esprit.

${ }^{7}$ It is interesting to highlight that moment derives in this sense from movement. In fact, time is a kind of indirect derivation of moment, a condensation movement. The momentum is then a contraction of movimentum (see Couchot, 2007: 26).

${ }^{8}$ Mitry, $1963^{\text {b }}$, p. 284: "Les images filmiques et leurs relations sont autant de stimulus qui «actualisent» des idées ou des émotions en rappelant à notre conscience des effets relatives à quelque expérience vécue."

${ }^{9}$ It is interesting to note that the VCR was an immense popular success because it enabled the personalization of broadcasting. In fact, it represented a first step towards the end of the hegemony of the Hertzian broadcast (see Stiegler, 2009).

${ }^{10}$ Eco, 2006 , p. 189: "una composizione, una narrazione, l'unificazione discorsiva di immagini isolate analiticamente nel contesto di una più vasta serie di avvenimenti compresenti ed intersecantisi."

11 "The development of this narrative is partly an effect of art and partly of nature. The result will be an odd interaction of spontaneity and artifice, in which artifice defines and chooses the spontaneity, but spontaneity, in its turn, determines the artifice both in its conception and its realization." (My translation.) 12 "If one rejects the plot, then one also recognizes the fact that the world is a knot of possibilities and that a work of art must reproduce that physiognomy." (My translation.)

13 "The narrative, as plot, does not exist because the director deliberately wants to transmit a feeling of suspension, of indeterminateness, he wants to frustrate fictional instincts in order that he can penetrate actively into the core of the fiction (which is in itself already a filtered life) to then move within a series of intellectual and moral dilemma. The opening presupposes, in short, a long and accurate organization of a field of possibilities." (My translation) 
HSS, vol. VI, no. 1(2017): 13-33

14 " The logic of this new level influences the internal organization of the data (the database) as much as the representation and communication of these same data influence the human component (the interface). At the same time, this logic displays expressive possibilities in both domains." (My translation)

${ }_{15}$ On the need to gather, archive and preserve knowledge and on the improvement of human ability to do so thanks to digital technology, see, among others, Zinna, 2004, especially, pp. 155-257, with references therein.

${ }^{16}$ As for this topic, consider also the phenomenon described by Bolter as topographic writing. According to Bolter, in contrast to topical writing - where topographic writing is not "the writing of a place, but rather a writing with places" - topographic writing was not a phenomenon exclusive to writing technology (Bolter, 1991: 25). In the cinematographic image, due to the externalization of the database, the narrative act progressively becomes a cartographic act, and in addition, a navigable space.

${ }^{17}$ This narrative phenomenon is called by Manovich "modularity." Dealing with HTML, Manovich, describes modularity as a "number of separated objects - GIF and JPEG images, media clips, Virtual Reality Modeling Language (VRML) scenes, Shockwave and Flash movies - which are all stored independently, locally, and/or on a network. In short, a new media object consist of independent parts, each of which consist of smaller independent parts, and so on, down to the level of the smallest 'atoms' - pixels, 3-D points, or text characters." (Manovich, 2001: $31)$.

\section{Biographical note:}

German A. Duarte obtained a Ph.D. degree in Media Studies at the RUHRUniversität Bochum and is currently professor of film studies and communication at the University of Bogotá Jorge Tadeo Lazano. His research interests include history of media, film history, cybernetics, cognitive-cultural economy and philosophy. 